\title{
Growth and Yield of Maize as Influenced by Sequential Application of Herbicides
}

\author{
Shaik Nazreen $^{1 *}$, D. Subramanyam ${ }^{2}$, N. Sunitha ${ }^{3}$ and V. Umamahesh ${ }^{4}$ \\ ${ }^{1}$ Department of Agronomy, ${ }^{2}$ Department of Agronomy, ${ }^{4}$ Department of Crop Physiology, \\ S.V. Agricultural College, Tirupati, India \\ ${ }^{3}$ Department of Agronomy, Regional Agricultural Research Station, Tirupati, India \\ Acharya N. G. Ranga Agricultural University, Lam, Guntur, Andhra Pradesh, India \\ *Corresponding author
}

Keywords

Halosulfuron-methyl,

Maize, Pre-

emergence, Post-

emergence, Weed

management practices,

Tembotrione

Article Info

Accepted:

20 April 2018

Available Online:

10 May 2018

\section{A B S T R A C T}

A total of ten treatments were evaluated in a randomized block design (RBD) with three replications on sandy loam soils of Tirupati, Andhra Pradesh. The treatments comprised of pre-emergence herbicides (alachlor $1000 \mathrm{~g} \mathrm{ha}^{-1}$ and atrazine $1000 \mathrm{~g}$ ha $\quad{ }^{-1}$ ) followed by post-emergence herbicides (Halosulfuron-methyl $67.5 \mathrm{~g}^{\mathrm{ha}}{ }^{-1}$, Tembotrione $100 \mathrm{~g}^{-1}$ and 2,4-D sodium salt). Among the different pre-and post-emergence herbicides applied, pre-emergence application of alachlor $1000 \mathrm{~g} \mathrm{ha}^{-1} \mathrm{fb}$ post-emergence application of halosulfuron-methyl $67.5 \mathrm{~g} \mathrm{ha}^{-1}+$ tembotrione $100 \mathrm{~g}$ ha imposed to maize resulted in higher number of yield attributes which ultimately results in higher grain yield. Unweeded check recorded the lowest values, which was due to severe weed competition. The yield reduction due to unweeded check accounts to 53.91 and 53.44 per cent.

\section{Introduction}

The renowed Nobel Laureate, Dr. Norman E. Borlaug believed that "The last two decades saw the revolution in rice and wheat, the next few decades will be known for maize era". Maize (Zea mays L.) is the most versatile and miracle food crop of global importance. It is cultivated in the tropics, sub-tropics, temperate and semi-arid regions. It is one of the most efficient crop gives high biological yield as well as grain yield in a short period of time due to its unique $\mathrm{C}_{4}$ photosynthetic mechanism. Maize is also called as "King of Cereals". It ranks third most important cereal crop after rice and wheat. In India, maize was cultivated in an area of 9.18 million hectares with a production of 24.17 million tonnes and average productivity of $2632 \mathrm{~kg} \mathrm{ha}^{-1}$ during 2014-15. In Andhra Pradesh, it was grown in an area of 3 lakh hectares with production of 19.38 lakh tonnes and average productivity of 
$6396 \mathrm{~kg} \quad \mathrm{ha}^{-1}$ during 2014-15 (www.indiastat.com). Low yield of maize under Indian conditions may be attributed due to number of factors, among them weeds rank as prime enemy. Hand weeding is the commonest and effective method of control of weeds, however, it is not only intensive, but also expensive and strenuous. The extent of yield loss due to weeds in maize varies from 28 to 93 per cent depending on the type of weed flora, intensity and duration of crop weed competition. Chemical weed management is the viable option in maize crop as highly selective post-emergence herbicides are available.

\section{Materials and Methods}

Field experiment was conducted during kharif season of 2016 on sandy loam soils of wetland farm of S. V. Agricultural College, Tirupati, Acharya N. G. Ranga Agricultural University, Andhra Pradesh, India. The experimental field was situated at about $13.5^{\circ} \mathrm{N}$ latitude and $79.5^{\circ} \mathrm{E}$ longitude, at an altitude of $182.9 \mathrm{~m}$ above the mean sea level in the Southern Agro-Climatic Zone of Andhra Pradesh. The soil of the experimental field was neutral in reaction ( $\mathrm{pH} 7.4)$, low in organic carbon $(0.63$ $\mathrm{dS} \mathrm{m} \mathrm{m}^{-1}$ ) and available nitrogen $\left(240 \mathrm{~kg} \mathrm{ha}^{-1}\right)$ and medium in available phosphorus (25.50 $\left.\mathrm{kg} \mathrm{ha}^{-1}\right)$ and available potassium (285 $\left.\mathrm{kg} \mathrm{ha}^{-1}\right)$. Ten treatments comprising of pre-emergence application of alachlor $1000 \mathrm{~g} \mathrm{ha}^{-1}\left(\mathrm{~W}_{1}\right)$, postemergence application of halosulfuron-methyl $67.5 \mathrm{~g} \mathrm{ha}^{-1}\left(\mathrm{~W}_{2}\right)$, post-emergence application of tembotrione $100 \mathrm{~g}$ ha $\quad{ }^{-1}\left(\mathrm{~W}_{3}\right)$, postemergence application of halosulfuron-methyl $67.5 \mathrm{~g} \mathrm{ha}^{-1}+$ tembotrione $100 \mathrm{~g} \mathrm{ha}^{-1}\left(\mathrm{~W}_{4}\right)$, preemergence application of alachlor $1000 \mathrm{~g} \mathrm{ha}^{-1}$ + post-emergence application of halosulfuronmethyl $67.5 \mathrm{~g} \quad \mathrm{ha}^{-1}\left(\mathrm{~W}_{5}\right)$, pre-emergence application of alachlor $1000 \mathrm{~g}$ ha ${ }^{-1}+$ postemergence application of tembotrione $100 \mathrm{~g}$ $\mathrm{ha}^{-1}\left(\mathrm{~W}_{6}\right)$, pre-emergence application of alachlor $1000 \mathrm{~g} \quad \mathrm{ha}^{-1} \mathrm{fb}$ post-emergence application of halosulfuron-methyl $67.5 \mathrm{~g} \mathrm{ha}^{-1}$ + tembotrione $100 \mathrm{~g} \mathrm{ha}^{-1}\left(\mathrm{~W}_{7}\right)$, pre-emergence application of atrazine $1000 \mathrm{~g}$ ha ${ }^{-1}+$ postemergence application of 2,4 D- sodium salt $800 \mathrm{~g} \mathrm{ha}^{-1}\left(\mathrm{~W}_{8}\right)$, two hand weedings at 20 and 40 DAS (W 9) and unweeded control (W 10) were assigned in a randomized block design with three replications. The recommended dose of fertilizers viz. $200 \mathrm{~kg} \mathrm{~N}, 60 \mathrm{~kg} \mathrm{P}_{2} \mathrm{O}_{5}$ and $50 \mathrm{~kg} \mathrm{~K}_{2} \mathrm{O} \mathrm{ha}{ }^{-1}$ were applied. Entire dose of phosphorous and potassium and $1 / 4^{\text {th }}$ dose of nitrogen were applied as basal. Remaining nitrogen was applied in splits at knee height, tasselling and silking stages.

All the herbicides alone or in combination were applied uniformly in the experimental plots with the help of knapsack sprayer fitted with flat fan nozzle using a spray volume of 500 1/ha. All the recommended agronomic and plant protection measures were adopted to raise crop. The data on weed density and weed dry weight were recorded at different growth stages of maize crop. These were subjected to square root transformation to normalize their distribution. Benefit-cost ratio was determined by dividing gross returns with cost of cultivation. Grain yield of maize along with other yield attributing characters like number of seeds $\operatorname{cob}^{-1}$ and test weight etc were recorded at harvest.

\section{Results and Discussion}

Major weed flora of the experimental field was Cyperus rotundus, Digitaria sanguinalis, Boerhavia erecta, Borreria hispida, Trichodesma indicum, Phyllanthus niruri and Digera arvensis. The lowest weed density and highest weed control efficiency were recorded with the treatment pre-emergence application of alachlor $1000 \mathrm{~g} \mathrm{ha}^{-1} \mathrm{fb}$ post-emergence application of halosulfuron-methyl $67.5 \mathrm{~g} \mathrm{ha}^{-1}$ + tembotrione $100 \mathrm{~g} \mathrm{ha}^{-1}$. While the lowest weed dry weight were noticed with hand weeding twice at 20 and 40 DAS. 
Table.1 Weed growth, yield components and yield of kharif maize as influenced by sequential application of herbicides and seedling vigour index of succeeding greengram

\begin{tabular}{|c|c|c|c|c|c|c|c|c|c|c|c|c|c|c|}
\hline Treatment & $\begin{array}{c}\text { Dose } \\
\left(\mathrm{g} \mathrm{ha}^{-1}\right)\end{array}$ & $\begin{array}{c}\text { Time of } \\
\text { application }\end{array}$ & $\begin{array}{l}\text { Weed } \\
\text { density } \\
\left(\mathbf{m}^{-2}\right)\end{array}$ & $\begin{array}{c}\text { Weed } \\
\text { dry } \\
\text { weight } \\
\left(\mathrm{g} \mathrm{m}^{-2}\right)\end{array}$ & $\begin{array}{c}\text { Weed } \\
\text { control } \\
\text { efficiency } \\
(\%)\end{array}$ & $\begin{array}{l}\text { Plant } \\
\text { height } \\
(\mathrm{cm})\end{array}$ & $\begin{array}{l}\text { Leaf } \\
\text { area } \\
\text { index }\end{array}$ & $\begin{array}{c}\text { Dry } \\
\text { matter } \\
\text { production } \\
\left(\mathrm{kg} \mathrm{ha}^{-1}\right)\end{array}$ & $\begin{array}{l}\text { Numbe } \\
\text { r of } \\
\text { seeds } \\
\text { cob }^{-1}\end{array}$ & $\begin{array}{c}\text { Test } \\
\text { weight } \\
\text { (g) }\end{array}$ & $\begin{array}{l}\text { Seed yield } \\
\left(\mathrm{kg} \mathrm{ha}^{-1}\right)\end{array}$ & $\begin{array}{c}\text { Straw } \\
\text { yield (kg } \\
\left.\text { ha }^{-1}\right)\end{array}$ & $\begin{array}{l}\text { Benefi } \\
\text { t-cost } \\
\text { ratio }\end{array}$ & $\begin{array}{l}\text { Seedlimg } \\
\text { vigour } \\
\text { index at } 15 \\
\text { DAS } \\
\text { (Greengra } \\
\text { m) }\end{array}$ \\
\hline Alachlor & 1000 & $1 \mathrm{DAS}$ & $\begin{array}{l}113.32 \\
(10.67)\end{array}$ & $\begin{array}{l}117.61 \\
(10.87)\end{array}$ & $\begin{array}{c}49.96 \\
(44.94)\end{array}$ & 168.56 & 1.33 & 9181 & 301.7 & 25.24 & 3494 & 5239 & 2.34 & 1814 \\
\hline $\begin{array}{l}\text { Halosulfuron- } \\
\text { methyl }\end{array}$ & 67.5 & 20 DAS & $\begin{array}{l}109.66 \\
(10.50)\end{array}$ & $\begin{array}{l}110.17 \\
(10.52)\end{array}$ & $\begin{array}{c}53.12 \\
(46.78)\end{array}$ & 163.24 & 1.10 & 7822 & 241.8 & 24.01 & 2954 & 4494 & 1.69 & 1813 \\
\hline Tembotrione & 100 & 20 DAS & $\begin{array}{l}114.99 \\
(10.74)\end{array}$ & $\begin{array}{l}132.95 \\
(11.55)\end{array}$ & $\begin{array}{c}43.43 \\
(41.21)\end{array}$ & 163.62 & 1.27 & 8626 & 248.2 & 24.78 & 3328 & 4977 & 2.01 & 1833 \\
\hline $\begin{array}{l}\text { Halosulfuron- } \\
\text { methyl } \mathrm{fb} \\
\text { tembotrione }\end{array}$ & $67.5+100$ & 20 DAS & $\begin{array}{l}72.65 \\
(8.55)\end{array}$ & $\begin{array}{l}41.08 \\
(6.45)\end{array}$ & $\begin{array}{c}82.52 \\
(65.27)\end{array}$ & 171.24 & 1.50 & 10025 & 325.5 & 26.56 & 3839 & 5671 & 1.94 & 1818 \\
\hline $\begin{array}{l}\text { Alachlor } \mathrm{fb} \\
\text { halosulfuron- } \\
\text { methyl }\end{array}$ & $1000+67.5$ & $1+20$ DAS & $\begin{array}{l}59.32 \\
(7.73)\end{array}$ & $\begin{array}{l}32.28 \\
(5.73)\end{array}$ & $\begin{array}{c}86.26 \\
(68.28)\end{array}$ & 182.8 & 1.66 & 10751 & 364.4 & 27.33 & 4186 & 5964 & 2.26 & 1928 \\
\hline $\begin{array}{l}\text { Alachlor } f b \\
\text { tembotrione } \\
\end{array}$ & $1000+100$ & $1+20$ DAS & $\begin{array}{l}55.99 \\
(7.52)\end{array}$ & $\begin{array}{l}71.74 \\
(8.50)\end{array}$ & $\begin{array}{c}69.47 \\
(56.48)\end{array}$ & 188.64 & 1.74 & 11086 & 390.0 & 28.35 & 4312 & 6081 & 2.46 & 1850 \\
\hline $\begin{array}{l}\text { Alachlor } \mathrm{fb} \\
\text { halosulfuron- } \\
\text { methyl+ } \\
\text { tembotrione } \\
\text { (Tank mix) }\end{array}$ & $\begin{array}{l}1000+67.5 \\
+100\end{array}$ & $1+20$ DAS & $\begin{array}{l}27.32 \\
(5.27)\end{array}$ & $\begin{array}{l}18.71 \\
(4.38)\end{array}$ & $\begin{array}{c}92.03 \\
(73.57)\end{array}$ & 198.33 & 1.87 & 12398 & 447.8 & 29.04 & 4863 & 6805 & 2.34 & 1964 \\
\hline $\begin{array}{l}\text { A trazine } f b \\
\text { 2,4-D Sodium } \\
\text { salt } \\
\end{array}$ & $1000+800$ & $1+20$ DAS & $\begin{array}{l}67.66 \\
(8.26)\end{array}$ & $\begin{array}{l}45.81 \\
(6.81)\end{array}$ & $\begin{array}{c}80.51 \\
(63.79)\end{array}$ & 176.64 & 1.58 & 10422 & 340.5 & 26.67 & 4054 & 5779 & 2.66 & 1835 \\
\hline $\begin{array}{l}\text { Two hand } \\
\text { weedings } \\
\end{array}$ & - & $\begin{array}{l}20 \text { and } 40 \\
\text { DAS }\end{array}$ & $\begin{array}{l}29.99 \\
(5.52)\end{array}$ & $\begin{array}{l}11.86 \\
(3.52)\end{array}$ & $\begin{array}{c}94.95 \\
(76.95)\end{array}$ & 192.86 & 1.81 & 11691 & 443.3 & 28.33 & 4554 & 6380 & 2.46 & 1959 \\
\hline $\begin{array}{l}\text { Unweeded } \\
\text { check }\end{array}$ & - & & $\begin{array}{l}209.32 \\
(14.49)\end{array}$ & $\begin{array}{l}235.05 \\
(15.35)\end{array}$ & - & 154.58 & 1.06 & 6526 & 206.4 & 23.58 & 2255 & 3960 & 1.62 & 1807 \\
\hline $\mathrm{CD}(\mathrm{P}=0.05)$ & & & 0.24 & 0.32 & 4.12 & 2.47 & 0.06 & 314 & 14.37 & 0.33 & 208.0 & 316.0 & 0.06 & 131 \\
\hline
\end{tabular}

Figures in parenthesis indicates square root transformed $(\sqrt{\mathrm{X}+0.5})$ values 
Fig.1 Dry matter production and plant height of maize at harvest as influenced by different weed management practices

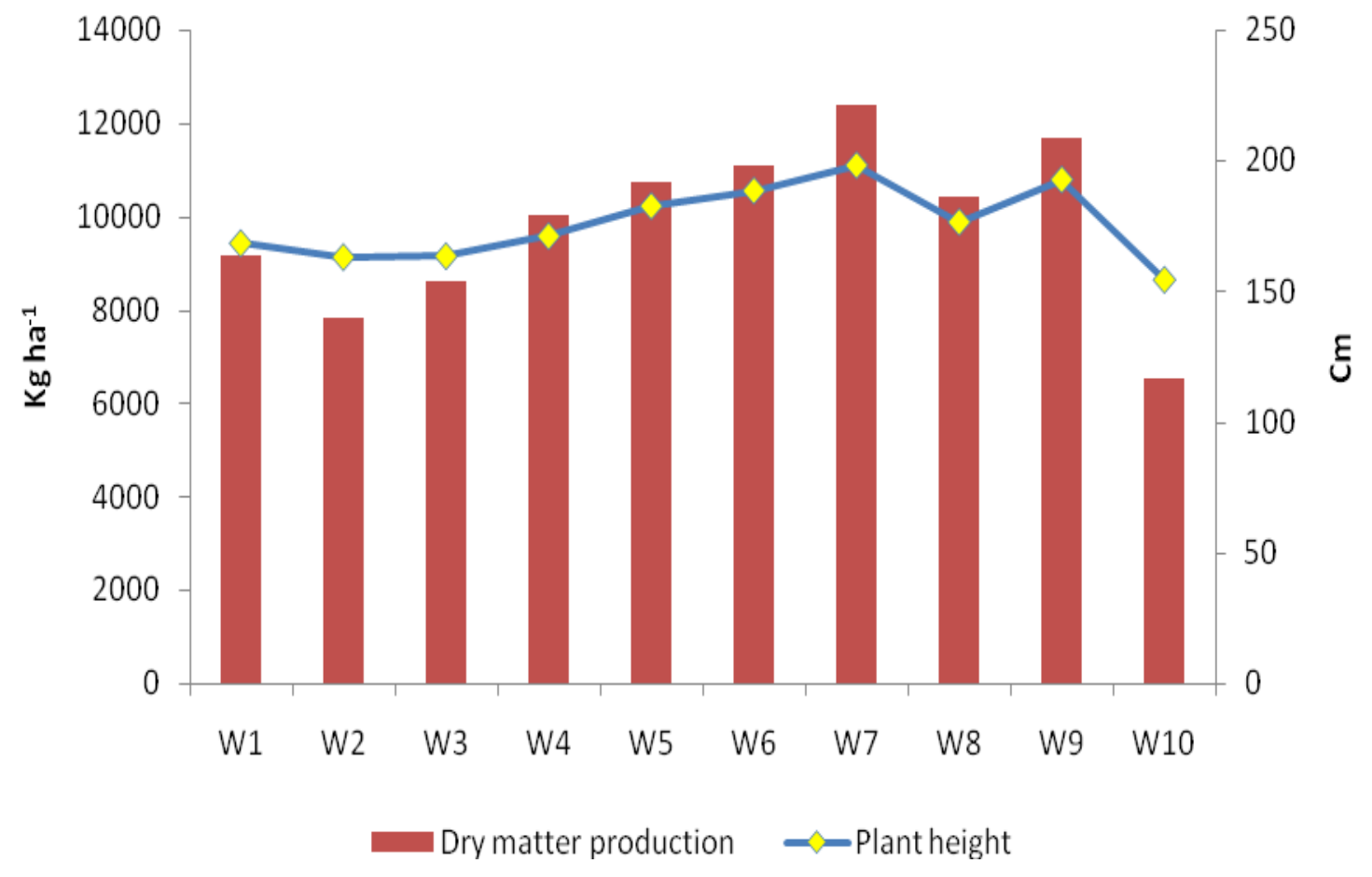

Fig.2 Leaf area index of maize at harvest as influenced by different weed management practices

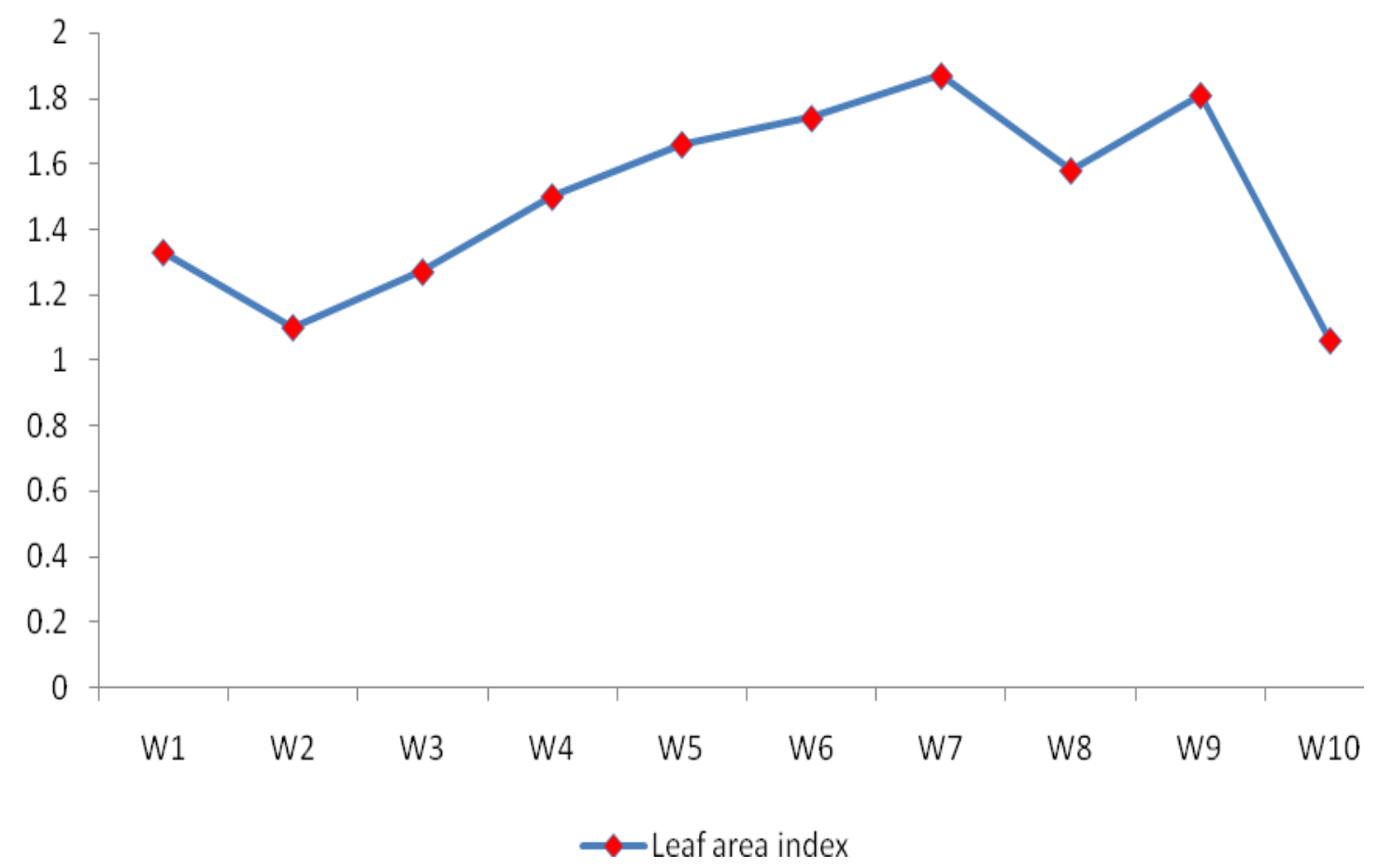


Fig.3 Number of grains $\operatorname{cob}^{-1}$ and test-weight of maize as influenced by different weed management practices

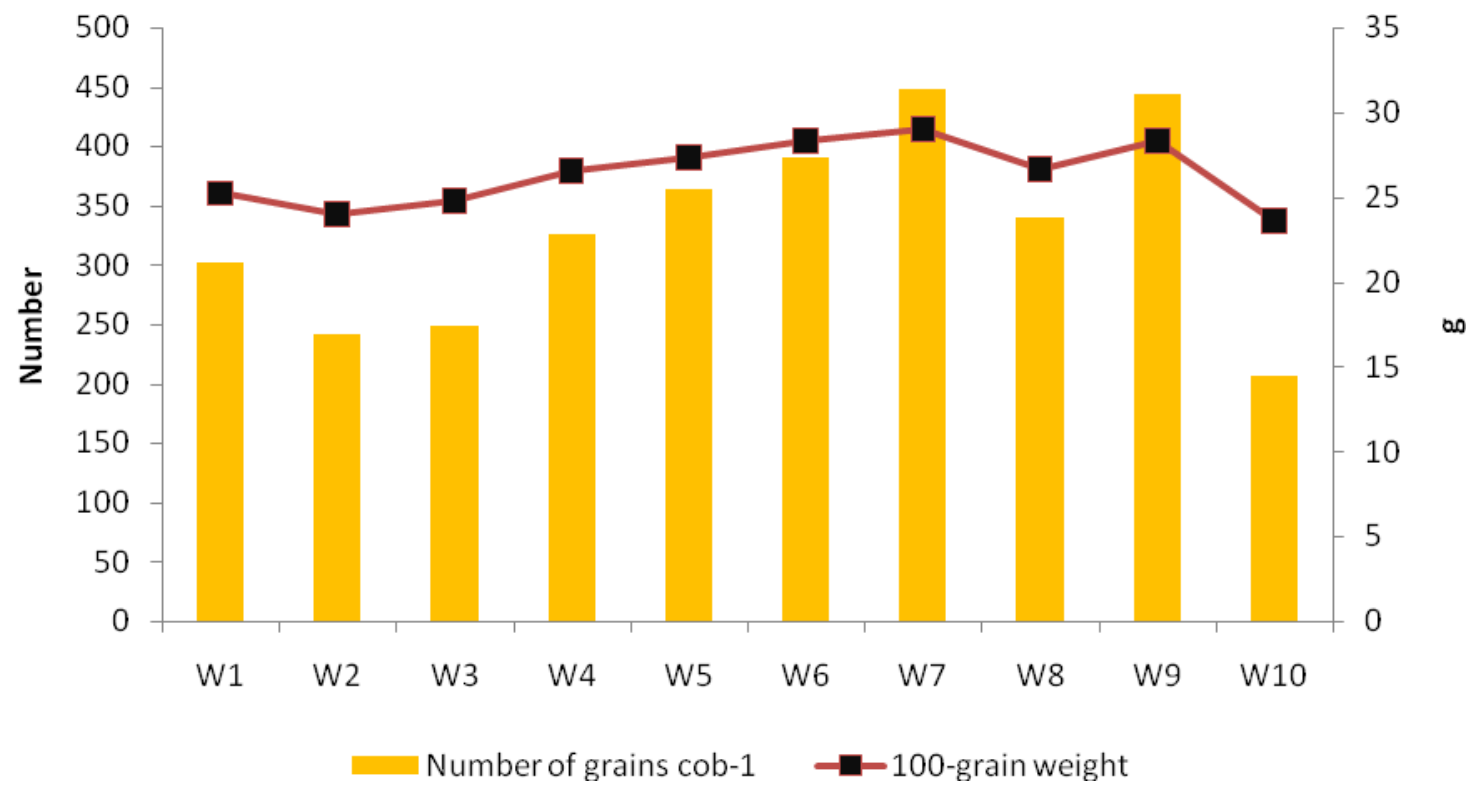

Fig.4 Seed yield and straw yield of maize as influenced by different weed management practices

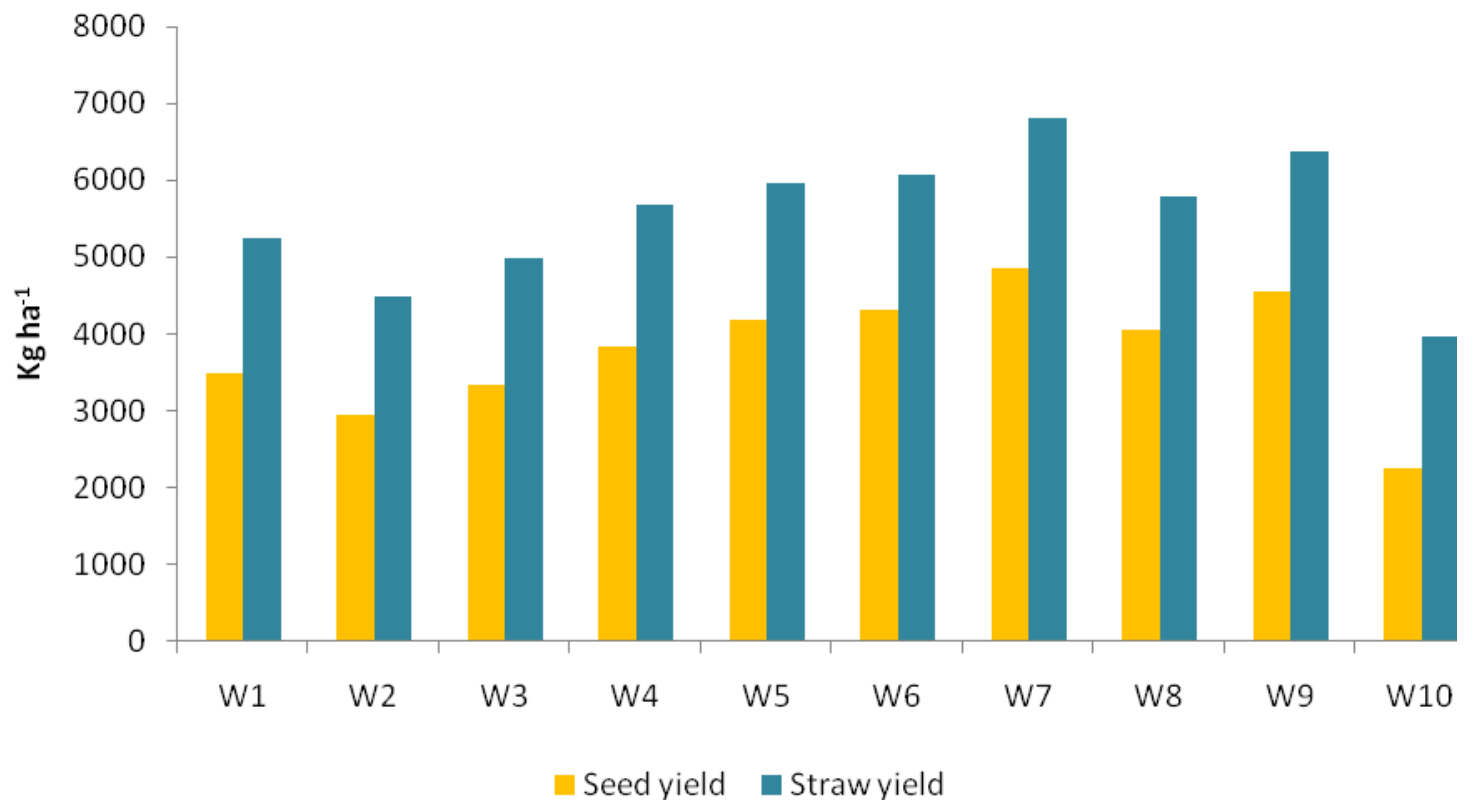

Different weed management practices emergence application of alachlor $1000 \mathrm{~g} \mathrm{ha}^{-1}$ exhibited significant influence on all the yield $f b$ post-emergence application of attributes studied (Table 1). Among them, the halosulfuron-methyl $67.5 \mathrm{~g} \mathrm{ha}^{-1}+$ tembotrione weed management practice with pre- $100 \mathrm{~g} \mathrm{ha}^{-1}$ recorded higher yield attributes, 
viz. plant height, leaf area index, dry matter production, number of seeds $\operatorname{cob}^{-1}$ and test weight followed by two hand weedings at 20 and 40 DAS. The higher plant height were noticed due to effective control of weeds, owing to reduced crop weed competition during the critical stages of crop growth, which inturn resulted in rapid cell multiplication and elongation, leading to increase in internodal length. These results are in conformity with findings of Abdullahi et al., (2016). Higher leaf area index might be due to lesser weed competition during early and critical stages of crop leads to better resource use efficiency, which in turn increased the number and size of the leaves. These results are in accordance with findings of Umesha et al., (2015). Higher dry matter production might be due to effective control of all the categories of weeds during the critical period of crop weed competition leads to production of more number of leaves plant $^{-1}$. Similar results were also reported by Pratap Singh et al., (2012). Higher number of seeds $\operatorname{cob}^{-1}$ and test weight might be due to better translocation of photosynthates from source to sink as a result of efficient utilization of growth resources because of weed free conditions. These results are in agreement with those of Pratik Sanodiya et al., (2013). The various weed management practices showed significant impact on seed yield of maize. Treatment pre-emergence application of alachlor $1000 \mathrm{~g} \mathrm{ha}^{-1} \mathrm{fb}$ postemergence application of halosulfuron-methyl $67.5 \mathrm{~g} \mathrm{ha}^{-1}+$ tembotrione $100 \mathrm{~g} \mathrm{ha}^{-1}$ registered highest seed yield and straw yield of maize followed by hand weeding twice at 20 and 40 DAS. Higher benefit-cost ratio was obtained with pre-emergence application of atrazine $1000 \mathrm{~g} a . i$ ha $^{-1} f b$ post-emergence application of 2,4-D sodium salt $800 \mathrm{~g}$ a.i ha ${ }^{-1}$, because of the lesser cost of chemicals. Higher seedling vigour index of succeeding greengram at 15 DAS was recorded with pre-emergence application of alachlor $1000 \mathrm{~g} \mathrm{ha}^{-1} \mathrm{fb}$ post- emergence application of halosulfuron-methyl $67.5 \mathrm{~g} \mathrm{ha}^{-1}+$ tembotrione $100 \mathrm{~g} \mathrm{ha}^{-1}$ applied to maize crop, which was however comparable with two hand weedings. The increased seedling vigour index in the above said weed management practice was mainly due to better root and shoot length as a result of reduced weed density and dry weight of weeds during early stages of greengram (Fig. $1-4)$.

It was concluded that pre-emergence application of alachlor $1000 \mathrm{~g} \mathrm{ha}^{-1} \mathrm{fb}$ postemergence application of halosulfuron-methyl $67.5 \mathrm{~g} \mathrm{ha}^{-1}+$ tembotrione $100 \mathrm{~g} \mathrm{ha}^{-1}$ was found to be a suitable and effective herbicidal weed management practice for kharif maize, because it controls weed density and dry weight very effectively, which ultimately results in increased yield attributes and yield of maize. The next best practice was two hand weedings followed by pre-emergence application of alachlor $1000 \mathrm{~g}$ a. $i \mathrm{ha}^{-1}+$ postemergence application of tembotrione $100 \mathrm{~g}$ a.i $\mathrm{ha}^{-1}$.

\section{References}

Abdullahi, S., Gautam Ghosh and Joy Dawson. 2016. Effect of different weed control methods on growth and yield of maize (Zea mays L.) under rainfed condition in Allahabad. IOSR Journal of Agriculture and Veterinary Science. 9 (4): 44-47.

Ankush Kumar, Rana, M.C and Sharma, N. 2017. Growth and yield of maize as influenced by different doses of tembotrione under mid-hill conditions of Himachal Pradesh. Biennieal Conference of the Indian Science on "Doubling Farmers Income by 2022: The role of weed Science", MPUA\&T, Udaipur, India during 1-3 March, pp. 187. 
Birendra Kumar, Ranvir Kumar, Suman Kalyani and Mizzanul Haque. 2013. Integrated weed management studies on weed flora and yield in kharif maize. Trends in Biosciences. 6 (2): 161-164.

Javid Ehsas, Desai, L.J., Ahir, N.B and Joshi, J.R. 2016. Effect of integrated weed management on growth, yield, yield attributes and weed parameters on summer maize (Zea mays L.) under south Gujarat condition. International Journal of Science, Environment and Technology. 5 (4): 2050-2056.

Mahadi, M.A. 2014. Growth, nutrient uptake and yield of maize (Zea mays L.) as influenced by weed control and poultry manure. International Journal of Science and Nature. 5 (1): 94-102.
Pratap Singh , V., Guru, S.K., Kumar, A., Akshita, B and Neeta Tripathi. 2012. Bioefficiency of tembotrione against mixed weed complex in maize. Indian Journal of Weed Science. 44 (1): 1-5.

Pratik Sanodiya, Jha, A.K and Arti Shrivastava. 2013. Effect of integrated weed management on seed yield of fodder maize. Indian Journal of Weed Science. 45 (3): 214-216.

Umesha, C., Sridhara, S and Aswini. 2015. Effect of pre and post emergent herbicides on growth, yield parameters and weed control efficiency in maize (Zea mays L.). Trends in Biosciences. 8 (10): 2468-2474.

www.indiastat.com

\section{How to cite this article:}

Shaik Nazreen, D. Subramanyam, N. Sunitha and Umamahesh, V. 2018. Growth and Yield of Maize as Influenced by Sequential Application of Herbicides. Int.J.Curr.Microbiol.App.Sci. 7(05): 2764-2770. doi: https://doi.org/10.20546/ijcmas.2018.705.321 